\title{
Regulation of expression of matrix metalloproteinase-9 by JNK in Raw 264.7 cells: presence of inhibitory factor(s) suppressing MMP-9 induction in serum and conditioned media
}

\author{
Yun-Song Lee ${ }^{1}$, Huong Thi Lan Tran \\ and Quang Van Ta \\ Department of Molecular Cell Biology \\ Sungkyunkwan University School of Medicine \\ Samsung Biomedical Research Institute \\ Suwon 440-746, Korea \\ ${ }^{1}$ Corresponding author: Tel, 82-31-299-6190; \\ Fax, 82-31-299-6209; E-mail, yslee@ @sku.edu \\ DOI 10.3858/emm.2009.41.4.029
}

Accepted 3 December 2008

Abbreviation: MMP-9, matrix metalloproteinase-9

\begin{abstract}
Matrix metalloproteinase-9 (MMP-9) secreted from macrophages plays an important role in tissue destruction and inflammation through degradation of matrix proteins and proteolytic activation of cytokines/chemokines. Whereas the MEK-ERK and PI3KAkt pathways up-regulate MMP-9 expression, regulation of MMP-9 by JNK remains controversial. Presently, we aimed to determine the role of JNK in MMP-9 regulation in Raw 264.7 cells. Inhibition of JNK by the JNK inhibitor SP600125 induced MMP-9 in the absence of serum and suppressed the expression of TNF- $\alpha$, IL- 6 and cyclooxygenase-2 in LPS-treated Raw 264.7 cells. In a knockdown experiment with small interfering RNA, suppression of JNK1 induced MMP-9 expression. Interestingly, mouse serum suppressed SP600125mediated MMP-9 induction, similar to IFN- $\gamma$. However, the inhibitory activity of mouse serum was not affected by pyridone 6 , which inhibits Janus kinase downstream to IFN- $\gamma$. In addition to mouse serum, conditioned media of Raw 264.7 cells contained the inhibitory factor(s) larger than $10 \mathrm{kDa}$, which suppressed SP600125- or LPS-induced MMP-9 expression. Taken together, these data suggest that JNK1 suppresses MMP-9 expression in the absence of serum. In addition, the inhibitory factor(s) present in serum or secreted from macrophages may negatively control MMP-9 expression.
\end{abstract}

Keywords: anthra(1,9-cd)pyrazol-6(2H)-one; autocrine communication; JNK mitogen-activated protein kinases; macrophages; matrix metalloproteinase 9; serum

\section{Introduction}

Macrophages may be crucial in inflammatory diseases including chronic obstructive pulmonary disease (Shapiro et al., 1999), atherosclerosis (Deguchi et al., 2006), arthritis (Blom et al., 2007), and tubulointerstitial kidney disease (Eardley et al., 2005) via the release of pro-inflammatory mediators. Macrophages additionally contribute to tissue destruction by the release of several proteases including matrix metalloproteinase-9 (MMP-9; also called gelatinase B) (Van de Steen et al., 2000; Vaday et al., 2001). MMP-9 is a protease that degrades extracellular matrix proteins including gelatin, collagen, elastin, and laminin (Opdenakker et al., 2001; Chakrabarti and Patel, 2005). In addition, MMP-9 modulates the activities of other proteases, growth factors, cytokines, and chemokines through proteolytic cleavage (Opdenakker et al., 2001; Atkinson et al., 2003; Lin et al., 2008). These activities indicate the important roles of MMP-9 in tissue destruction and also in tissue remodeling and inflammation.

MMP-9 regulation involves transcriptional regulation, post-translational cleavage, and antagonism by physiological inhibitors (Chakraborti et al., 2003; Yan and Boyd, 2007). In transcriptional regulation, MMP-9 expression is controlled by transcriptional factors including AP-1 and NF-kB, which bind to the corresponding binding sites in the MMP-9 promoter region (Benbow et al., 1997). In various kinds of cells, different stimuli induce MMP-9 expression through activation of the MEK-ERK or phosphoinositide 3-kinase (PI3K)-Akt signaling pathways, which subsequently activate $\mathrm{AP}-1$ and $\mathrm{NF}-\mathrm{\kappa B}$ (Gum et al., 1997; Genersch et al., 2000; Chung et al., 2004; Moon et al., 2004; Woo et al., 2004a; Cheng et al., 2006; Han et al., 2006). Also, p38 MAPK up-regulates MMP-9 expression in Raw 264.7 cells stimulated with LPS (Woo et al., 2004) and CpG oligodeoxynucleotide (Lim et al., 2007). 
In comparison with ERK and p38 MAPK, however, the regulatory role of JNK in MMP-9 expression remains contentious. Inhibition of JNK activity by the JNK inhibitor SP600125 decreases MMP-9 expression in ovarian carcinoma cells stimulated with PMA (Shin et al., 2002), astrocytes stimulated with IL-1 $\beta$ (Wu et al., 2004), and cardiac fibroblasts stimulated with IL-1 $\beta$ (Xie et al., 2004). Similarly, knockdown of JNK2 by siRNA also inhibits MMP-9 expression induced by TNF- $\alpha$ in A549 cells (Lin et al., 2008). In contrast, SP600125 does not suppress MMP-9 expression in Raw 264.7 cells stimulated with LPS (Woo et al., 2004) and does not inhibit MMP-9 expression induced by PMA in rat astrocytes, even though PMA activates JNK (Arai et al., 2003).

In this study, we demonstrate that JNK1, but not JNK2, suppresses LPS-induced MMP-9 expression in Raw 264.7 cells in the absence of serum. Additionally, we reveal that the presence of the inhibitory factor(s) in serum that represses MMP-9 expression induced by JNK inhibition. Finally, we report the presence of a similar autocrine inhibitory activity in the conditioned media of Raw 264.7 cells.

\section{Results}

\section{SP600125 augments MMP-9 induction in Raw 264.7 cells stimulated by LPS or TNF- $\alpha$}

We first checked the effect of the JNK inhibitor SP600125 on induction of MMP-9 in comparison with other genes already known to be up-regulated through JNK by LPS stimulation (Matsuguchi et al., 2001; Waetzig et al., 2005). Before stimulation, Raw 264.7 cells were deprived of serum overnight with DMEM containing $0.02 \%$ BSA. Then, $10 \mu \mathrm{M}$
SP600125 was added to the cells $1 \mathrm{~h}$ prior to stimulation with $100 \mathrm{ng} / \mathrm{ml}$ LPS. Total RNA or culture medium was collected after $8 \mathrm{~h}$ for MMP-9 RT-PCR or after $24 \mathrm{~h}$ for MMP-9 gelatin zymography. As shown in Figure 1A, LPS induced the expression of TNF- $\alpha$, IL-6, and COX-2 mRNA in Raw 264.7 cells. These inductions were abrogated by $10 \mu \mathrm{M}$ SP600125. These observations indicate that induction of TNF- $\alpha$, IL-6, or COX-2 mRNA by LPS is up-regulated by JNK in Raw 264.7 cells.

Similarly, LPS and TNF- $\alpha$ increased both MMP-9 mRNA expression and MMP-9 secretion (a pro-form of MMP-9, Figure 1B). However, in contrast to TNF- $\alpha$, IL-6, and COX-2 expression, both MMP-9 expression and MMP-9 secretion was augmented by $10 \mu \mathrm{M}$ SP600125. Interestingly, SP600125 elevated basal levels of MMP-9 mRNA expression and MMP-9 secretion without stimulation of LPS or TNF- $\alpha$.

\section{SP600125 induces basal expression of MMP-9 in a time- and concentration-dependent manner}

As SP600125 increased the basal expression of MMP-9 even without LPS or TNF- $\alpha$ (Figure 1B), we next characterized the effect of SP600125 on basal MMP-9 expression. In the absence of SP600125, both MMP-9 mRNA expression and MMP-9 secretion gradually increased according to the time of incubation in Raw 264.7 cells cultured in $0.02 \%$ BSA-containing medium (Figure 2A). However, SP600125 elevated MMP-9 mRNA expression to a much greater extent at $8 \mathrm{~h}$ and $24 \mathrm{~h}$. Accordingly, a marked increase in MMP-9 activity was observed in SP600125-treated Raw 264.7 cells at $24 \mathrm{~h}$. The inductive effect of SP600125 on MMP-9 expression was concentration-dependent (Figure 2B). Both MMP-9 mRNA expression and MMP-9 secre-
A

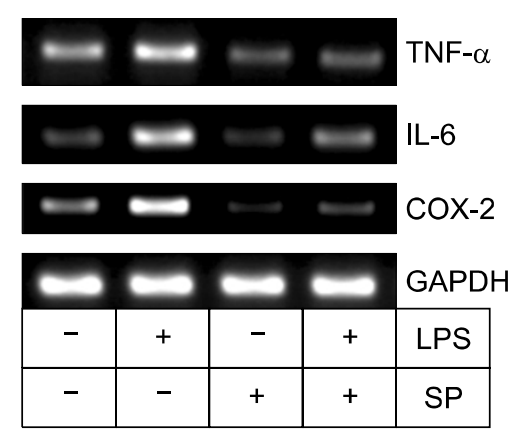

B

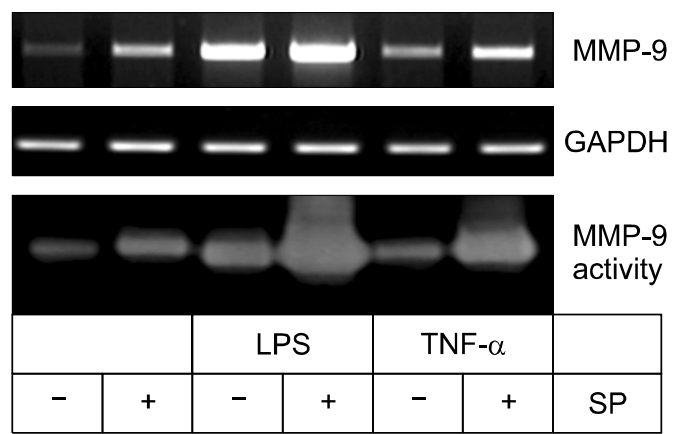

Figure 1. SP600125 augments MMP-9 induction in Raw 264.7 cells stimulated by LPS or TNF- $\alpha$. (A) Raw 264.7 cells were pretreated with $10 \mu M$ SP600125 $1 \mathrm{~h}$ prior to stimulation with $100 \mathrm{ng} / \mathrm{ml}$ LPS. Total RNAs were collected $8 \mathrm{~h}$ later and RT-PCR was performed with specific primers for TNF- $\alpha$, IL-6, or COX-2. (B) Raw 264.7 cells were pretreated with $10 \mu \mathrm{M}$ SP600125 $1 \mathrm{~h}$ prior to stimulation with $100 \mathrm{ng} / \mathrm{ml}$ LPS or $100 \mathrm{ng} / \mathrm{ml}$ TNF- $\alpha$. Total RNAs or culture media were collected after $8 \mathrm{~h}$ for MMP-9 RT-PCR or after $24 \mathrm{~h}$ for MMP-9 gelatin zymography. 
A

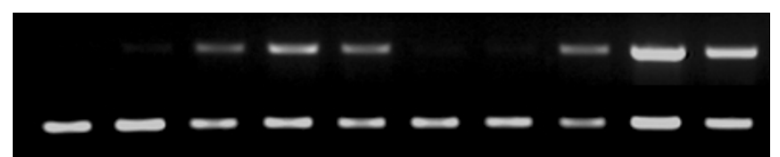

MMP-9

GAPDH

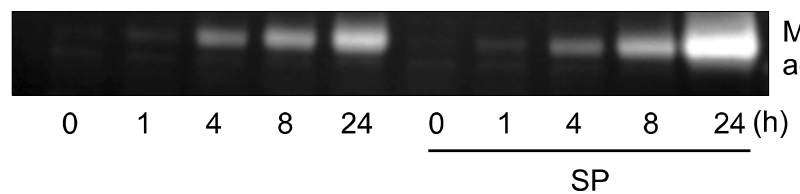

B

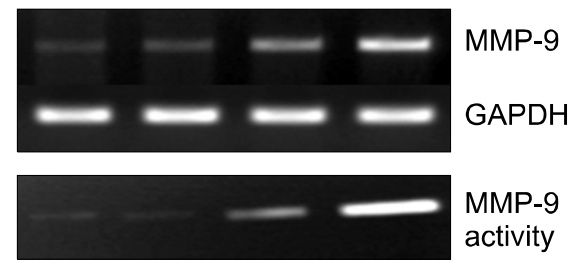

0

$0.1 \quad 1$

$10(\mu \mathrm{M})$

C

\begin{tabular}{|c|c|c|c|c|c|c|c|c|c|c|}
\hline 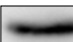 & - & - & $2=$ & $=$ & 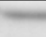 & - & en & & $=$ & p-cJu \\
\hline & & & & & & & & & & $\alpha$-tub \\
\hline \multicolumn{2}{|c|}{$10 \mathrm{~min}$} & \multicolumn{2}{|c|}{$1 \mathrm{~h}$} & \multicolumn{2}{|c|}{$2 \mathrm{~h}$} & \multicolumn{2}{|c|}{$4 \mathrm{~h}$} & \multicolumn{2}{|c|}{$8 \mathrm{~h}$} & \\
\hline- & + & - & + & - & + & - & + & - & + & SP \\
\hline
\end{tabular}

D

\begin{tabular}{|c|c|c|c|c|c|c|c|l|}
\hline \multicolumn{10}{|c|}{} & \multicolumn{1}{l}{ MMP-9 } \\
\hline 0 & 2 & 4 & 8 & 0 & 2 & 4 & 8 & Time (h) \\
\hline+ & + & + & + & + & + & + & + & SP600125 \\
\hline- & - & - & - & + & + & + & + & Actinomycin D \\
\hline
\end{tabular}

Figure 2. SP600125 induces basal expression of MMP-9. (A) Time-dependent induction of MMP-9 by SP600125. Raw 264.7 cells were treated with 10 $\mu \mathrm{M}$ SP600125. At the indicated times, total RNAs and culture media were collected for MMP-9 RT-PCR and MMP-9 zymography, respectively. (B) Concentration-dependent MMP-9 induction. Raw 264.7 cells were treated with various concentrations of SP600125. Total RNAs or culture media were collected after $8 \mathrm{~h}$ for MMP-9 RT-PCR or after $24 \mathrm{~h}$ for MMP-9 gelatin zymography. (C) After Raw 264.7 cells were treated with $10 \mu \mathrm{M}$ SP600125, the cells were collected for determination of c-jun phosphorylation by Western blot. (D) For determination of regulation level of MMP-9 expression, Raw 264.7 cells were pre-treated with actinomycin D $(5 \mu \mathrm{g} / \mathrm{ml}) 1 \mathrm{~h}$ prior to $10 \mu \mathrm{M} \mathrm{SP600125.} \mathrm{At} \mathrm{the} \mathrm{indicated} \mathrm{times,} \mathrm{the} \mathrm{cells} \mathrm{were} \mathrm{collected} \mathrm{and} \mathrm{MMP-9} \mathrm{expression}$ was determined.

tion were increased by SP600125 in a concentration-dependent manner.

To confirm whether the inducing effect of SP600125 on MMP-9 expression was mediated through JNK activity, phosphorylation of the JNK substrate c-Jun was determined after treatment with SP600125. As shown in Figure 2C, phosphorylation of c-Jun decreased from $10 \mathrm{~min}$ to $8 \mathrm{~h}$ after SP600125 treatment.

Next, we determined the level of regulation of MMP-9 expression by SP600125. Raw 264.7 cells were pre-treated with actinomycin $\mathrm{D} 1 \mathrm{~h}$ prior to 10 $\mu \mathrm{M}$ SP600125. As shown in Figure 2D, actinomycin $D$ successfully inhibited MMP-9 induction by
SP600125 at $8 \mathrm{~h}$. This data indicates that SP600125 induced MMP-9 mRNA at transcriptional level.

\section{Effects of SP600125 on ERK, p38 MAPK, Akt, and NF- $\mathrm{kB}$}

As ERK, p38 MAPK, or Akt mediate MMP-9 induction (Chung et al., 2004), we tried to determine the effects of SP600125 on the activation of ERK, p38 MAPK, or Akt. As shown in Figure 3A, SP600125 did not elevate the phosphorylation of ERK, p38 MAPK, or Akt. Furthermore, SP600125 did not affect the phosphorylation of p65, which is a component of $\mathrm{NF}-\kappa \mathrm{B}$ involved in the induction of 
A

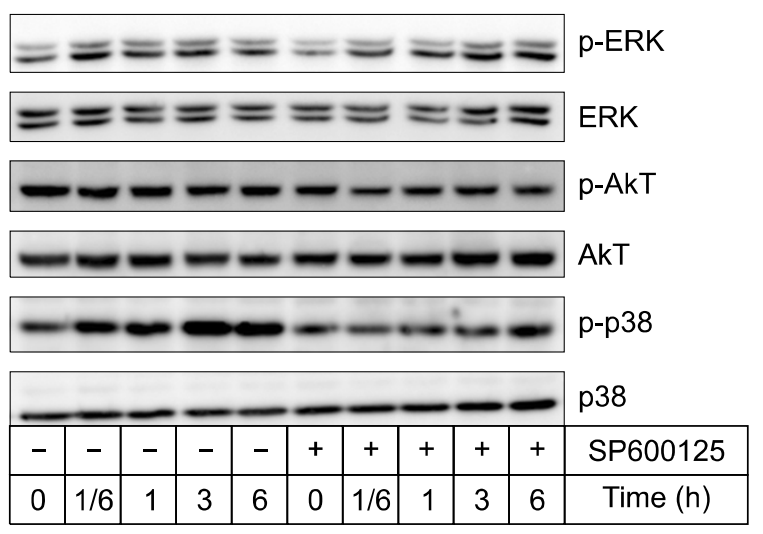

B

\begin{tabular}{|c|c|c|c|c|c|c|c|c|c|c|}
\hline \multicolumn{3}{|c|}{$+4=$} & & & & & & & 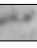 & \multirow{2}{*}{$\begin{array}{l}\text { p-p65 } \\
\text { p65 }\end{array}$} \\
\hline - & $=$ & $=$ & $=$ & - & - & - & $=$ & - & - & \\
\hline - & + & - & + & - & + & - & + & - & + & SP600125 \\
\hline $1 /$ & & & 1 & & 2 & & 4 & 8 & & Time $(\mathrm{h})$ \\
\hline
\end{tabular}

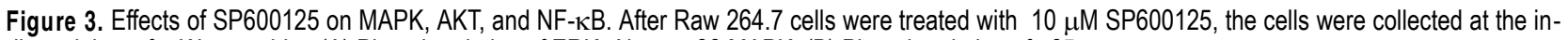
dicated times for Western blot. (A) Phosphorylation of ERK, Akt, or p38 MAPK. (B) Phosphorylation of p65.

MMP-9 (Figure 3B). These results suggest that SP600125 may not induce MMP-9 expression through the activation of ERK, p38 MAPK, Akt, or p65 of $N F-\kappa B$.

\section{Suppression of MMP-9 expression by JNK1}

Next, we performed a knock-down experiment to exclude a nonspecific effect of SP600125 and to identify JNK isoform involved in the negative regulation of MMP-9 expression, in light of different potential biological roles of JNK1 and JNK2 (Bogoyevitch, 2006). JNK1 or JNK2 siRNA successfully suppressed levels of JNK1 or JNK2 protein, respectively (Figure 4A). Knock-down of JNK1 by JNK1 siRNA increased both MMP-9 mRNA expression
A

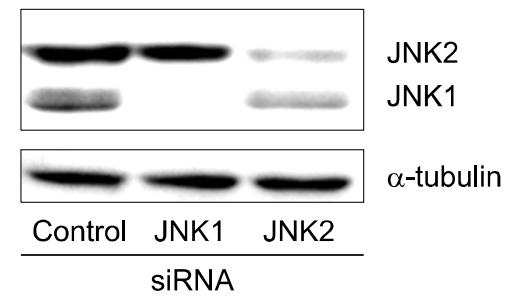

C

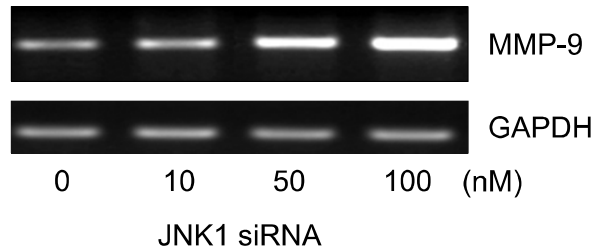

B
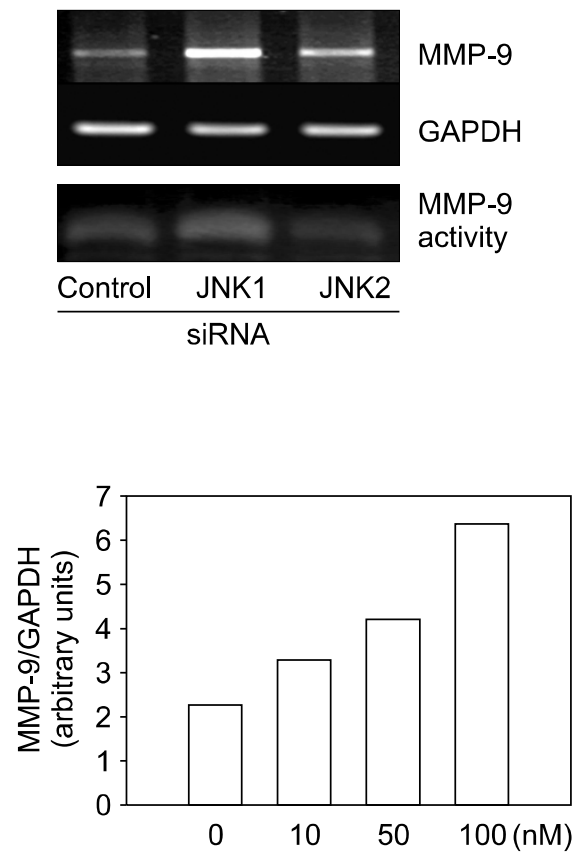

Figure 4. Suppression of MMP-9 expression by JNK1. Raw 264.7 cells $\left(2 \times 10^{5}\right)$ were transfected with negative control, JNK1, or JNK2 siRNA. (A) Levels of JNK1and JNK2 proteins in Western blot, and (B) MMP-9 mRNA expression and MMP-9 secretion after transfection of $100 \mathrm{nM}$ each siRNA. (C) Induction of MMP-9 expression in a concentration-dependent manner. Raw 264.7 cells were transfected with increasing concentrations of JNK siRNA. After $72 \mathrm{~h}$, total RNAs were collected for MMP-9 RT-PCR. 
and MMP-9 secretion (Figure 4B). In addition, JNK1 siRNA increased MMP-9 expression in a concentration-dependent manner (Figure 4C). In contrast, JNK2 siRNA induced MMP-9 expression to a much lesser degree. However, it may not be conclusive that JNK2 siRNA caused MMP-9 induction, because JNK2 siRNA slightly inhibited JNK1 expression. These data suggest that JNK1 can specifically suppress basal MMP-9 expression in Raw 264.7 cells.

\section{Serum inhibits SP600125-mediated MMP-9 induction}

The above experiments were performed in the absence of serum to exclude influence of serum. Next, we tried to confirm SP600125-mediated MMP-9 in- duction in the presence of different concentrations of mouse serum and FBS. Surprisingly, SP600125mediated induction of MMP-9 was attenuated by $10 \%$ mouse serum or FBS (Figure $5 \mathrm{~A}$ ). FBS displayed weaker inhibitory effect than did mouse serum. Next, Raw 264.7 cells were treated with different concentrations of mouse serum (2.5-10\%). Mouse serum inhibited both basal and SP60015induced MMP-9 expression in a concentrationdependent manner (Figure 5B). Both basal and SP600125-induced MMP-9 expression was almost completely abolished by $10 \%$ mouse serum. As IFN- $\gamma$ is known to inhibit MMP-9 expression (Xie et al., 1994), we investigated whether IFN- $\gamma$ was responsible for MMP-9 suppression in mouse
A

\begin{tabular}{|c|c|c|c|c|c|c|c|c|}
\hline MMP-9 & 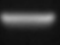 & - & - & 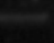 & ح- & 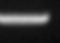 & - & $=$ \\
\hline GAPDH & & & & 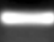 & & 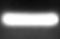 & 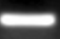 & - \\
\hline SP600125 & - & - & - & - & + & + & + & + \\
\hline \multirow[t]{2}{*}{$\%$} & 0.5 & 10 & 0.5 & 10 & 0.5 & 10 & 0.5 & 10 \\
\hline & \multicolumn{2}{|c|}{ FBS } & \multicolumn{2}{|c|}{ MS } & \multicolumn{2}{|c|}{ FBS } & \multicolumn{2}{|c|}{ MS } \\
\hline
\end{tabular}

B

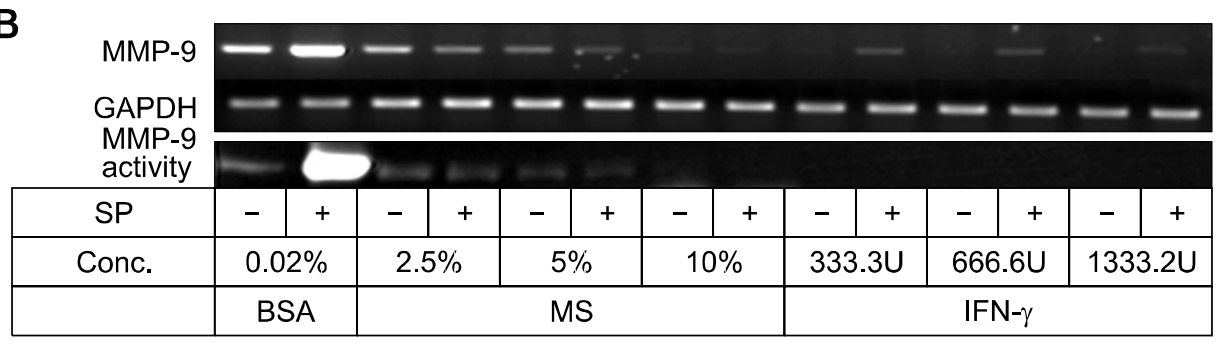

C

\begin{tabular}{|c|c|c|c|c|c|c|c|c|c|c|c|c|}
\hline \multicolumn{13}{|c|}{$--\infty$} \\
\hline GAPDH & - & - & - & - & - & - & - & $\longrightarrow$ & - & - & - & - \\
\hline $\begin{array}{l}\text { MMP-9 } \\
\text { activity }\end{array}$ & & 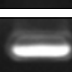 & - & & 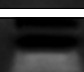 & $=$ & 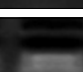 & $=$ & & $=$ & - & $\longrightarrow$ \\
\hline $\mathrm{SP}$ & - & + & - & + & - & + & - & + & - & + & - & + \\
\hline \multirow[t]{2}{*}{ P6 } & - & - & + & + & - & - & + & + & - & - & + & + \\
\hline & \multicolumn{4}{|c|}{$0.02 \% \mathrm{BSA}$} & \multicolumn{4}{|c|}{$5 \% \mathrm{MS}$} & \multicolumn{4}{|c|}{333.3 U IFN- $\gamma$} \\
\hline
\end{tabular}

D

\begin{tabular}{|c|c|c|c|c|c|c|c|c|c|c|c|c|}
\hline $\begin{array}{l}p-J N K 2 \\
p-J N K 1\end{array}$ & $\overline{=}$ & $=$ & $=$ & $=$ & 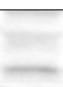 & $\bar{I}$ & 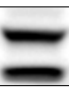 & $\bar{z}$ & $\bar{z}$ & $\bar{z}$ & \multicolumn{2}{|c|}{-} \\
\hline GAPDH & & & & & & & & & & & & \\
\hline Time (h) & 0 & 1 & 3 & 0 & 1 & 3 & 0 & 1 & 3 & 0 & 1 & 3 \\
\hline SP & - & - & - & + & + & + & - & - & - & + & + & + \\
\hline $5 \% \mathrm{MS}$ & - & - & - & - & - & - & + & + & + & + & + & + \\
\hline
\end{tabular}

Figure 5. Serum inhibits SP600125mediated MMP-9 induction. (A) Raw 264.7 cells were treated with 0.5 or $10 \%$ FBS or mouse serum $1 \mathrm{~h}$ prior to $10 \mu \mathrm{M}$ SP600125. After $8 \mathrm{~h}$, total RNAs were collected for MMP-9 RT-PCR. (B) Raw 264.7 cells were pretreated with increasing concentrations of mouse serum or mouse IFN- $\gamma .1 \mathrm{~h}$ later, $10 \mu \mathrm{M}$ SP600125 was added. Total RNAs or culture media were collected after $8 \mathrm{~h}$ for MMP-9 RT-PCR or after $24 \mathrm{~h}$ for MMP-9 gelatin zymography. (C) Raw 264.7 cells were pretreated with $250 \mathrm{nM}$ pyridone $1 \mathrm{~h}$ prior to mouse serum or IFN- $\gamma$. $1 \mathrm{~h}$ later, 10 $\mu \mathrm{M}$ SP600125 was added. Total RNAs or culture media were collected after $8 \mathrm{~h}$ for MMP-9 RT-PCR or after $24 \mathrm{~h}$ for MMP-9 gelatin zymography. (D) Raw 264.7 cells were treated with $5 \%$ mouse serum 30 min prior to $10 \mu \mathrm{M} \mathrm{SP600125.} \mathrm{At}$ the indicated times, the cells were collected for determination of JNK phosphorylation by Western blot. 
serum. INF- $\gamma$ reduced both basal and SP600125induced MMP-9 expression similar to the mouse serum in a concentration-dependent manner (Figure $5 B)$. However, while P6, a pan-JAK inhibitor, completely restored SP600125-mediated MMP-9 induction, it did not affect the inhibitory activity of mouse serum on MMP-9 expression (Figure 5C). As JNK1 siRNA induced MMP-9 expression and mouse serum suppressed MMP-9 induction by SP600125, we determined effect of mouse serum on activated status of JNK. In Figure 5D, SP600125 inhibited phosphorylation of JNK1 and JNK2, and mouse serum restored phosphorylation of JNK1 but not JNK2. These data imply that inhibitory factor(s) other than IFN- $\gamma$ suppress MMP-9 expression and mouse serum suppressed MMP-9 expression possibly through maintenance of JNK1 activity.

\section{The inhibitory factor(s) in the mouse serum exceed 10 kDa}

To characterize the nature of the inhibitory factor(s) in the mouse serum, the serum was fractionated and concentrated 2-fold by an ultrafiltration unit having a membrane with a $10 \mathrm{kDa}$ molecular weight cutoff. Whereas the lower fraction passing through the membrane did not suppress SP600125-induced MMP-9 secretion, the upper fraction containing molecules $>10 \mathrm{kDa}$ inhibited the increase in MMP-9 secretion to a greater extent than unfiltered mouse serum (Figure 6).

\section{Presence of inhibitory factor(s) in conditioned media of Raw 264.7 cells}

We hypothesized that inhibitory factor(s) may be secreted from Raw 264.7 cells, because basal and SP600125-induced expression of MMP-9 mRNA were lower at $24 \mathrm{~h}$ than at $8 \mathrm{~h}$ in Figure $2 \mathrm{~A}$. The inhibitory activity on MMP-9 expression was determined in the conditioned media of Raw 24.7 cells.

\begin{tabular}{|c|c|c|c|c|c|}
\hline \multicolumn{7}{|c|}{} & MMP-9 activity \\
\hline- & + & + & + & + & SP600125 \\
\hline $\begin{array}{c}\text { None } \\
(0.02 \% \text { BSA })\end{array}$ & Total & Lower & Upper & $\begin{array}{c}2.5 \% \\
\text { Mouse serum }\end{array}$ \\
\hline
\end{tabular}

Figure 6. The inhibitory factor(s) in the mouse serum is larger than 10 $\mathrm{kDa}$. Mouse serum was fractionated and concentrated 2-fold with an ultrafiltration unit having a $10 \mathrm{kDa}$ molecular weight cutoff. Raw 264.7 cells were pretreated with $0.02 \% \mathrm{BSA}, 2.5 \%$ mouse serum, $2.5 \%$ filtered fraction (lower), or $2.5 \%$ of unfiltered fraction (upper) $4 \mathrm{~h}$ prior to the addition of $10 \mu \mathrm{M}$ SP600125. Culture media was collected $24 \mathrm{~h}$ later for MMP-9 zymography.
To obtain the media, Raw 264.7 cells were cultured in the absence of serum and the conditioned media were added to fresh culture media at final concentrations from 5-20\% (Figure 7A). SP600125mediated increase in MMP-9 secretion was inhibited by $20 \%$ conditioned media. In addition, the concentrated conditioned media also inhibited MMP-9 induction by LPS (Figure 7B). These data are consistent with the suggestion that the presence of inhibitory factor(s) secreted from Raw 264.7 cells can suppress MMP-9 expression induced by JNK inhibition or LPS stimulation.

\section{Discussion}

In this study, we have demonstrated that knockdown of JNK1, but not JNK2, induces MMP-9 mRNA expression and MMP-9 secretion in Raw 264.7 cells. Even with structural and biochemical similarities, JNK1 and JNK2 do not simply redundantly perform the same cellular and biological functions. For example, whereas JNK1 phosphorylates and activates transcriptional activity of c-Jun, JNK2 is preferentially bound to c-Jun in unstimulated cells and contributes to the degradation of c-Jun (Sabapathy et al., 2004). Ablation of JNK1 decreases TATA-binding protein expression, whereas ablation

\section{A}

\begin{tabular}{|c|c|c|c|c|c|c|c|c|}
\hline \multicolumn{1}{|c|}{} & \multicolumn{1}{|c|}{} \\
\hline- & + & - & + & - & + & - & + & SP600125 \\
\hline & & $5 \%$ & $10 \%$ & $20 \%$ & $\begin{array}{c}\text { Conditioned } \\
\text { media }\end{array}$ \\
\hline
\end{tabular}

B

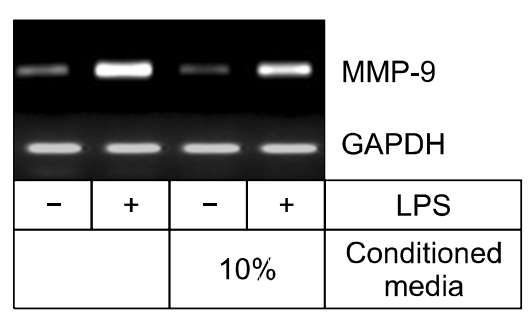

Figure 7. Presence of inhibitory factor(s) in conditioned media of Raw 264.7 cells. (A) Suppression of MMP-9 secretion by the conditioned media. The conditioned media was obtained after 1 day culture of Raw 264.7 cells in the absence of serum and BSA. Conditioned media were added to the fresh culture media at final concentrations from $5-20 \% .4 \mathrm{~h}$ later, $10 \mu \mathrm{M}$ SP600125 was added to the cells. Culture media was collected $24 \mathrm{~h}$ later for MMP-9 zymography. (B) The conditioned media obtained in (A) was concentrated 15 -fold and was added to the cells at a final concentration of $10 \% .4 \mathrm{~h}$ later, the cells were stimulated with 100 $\mathrm{ng} / \mathrm{ml}$ LPS. Total RNAs were collected after $8 \mathrm{~h}$ for MMP-9 RT-PCR. 
of JNK2 enhances it (Zhong et al., 2007). In addition, JNK1, but not JNK2, plays a predominant role in the induction of pro-inflammatory cytokine from bone marrow macrophages in response to LPS and TNF- $\alpha$ (Sánchez-Tilló et al., 2007). However, differential regulation of MMP-9 by JNK1 or JNK2 has remained unclear due to an absence of comparative experimental data, even though JNK1 may induce MMP-9 (Wang et al., 2008; Crowe et al., 2001) without comparison with JNK2. In contrast, our data clearly indicate the distinct role of JNK1 in the regulation of MMP-9 expression in comparison with JNK2.

The presently documented suppressive role of JNK1 in MMP-9 expression is contradictory to previous findings. IL-1 $\beta$-activated JNK increases MMP-9 expression in rat cardiac fibroblasts (Xie et al., 2004) and rat brain astrocytes (Wu et al., 2004). In ovarian carcinoma cells, inhibition of JNK reduces the secretion of MMP-9 induced by PMA (Shin et al., 2002). Activation of JNK is related to increased MMP-9 expression induced by TNF- $\alpha$ in A549 cells (Lin et al., 2008). In contrast to these reports, Heidinger et al. (2006) observed similar results to ours. In THP-1 monocytic cells, MMP-9 expression was augmented by SP600125 together with upregulation of ERK phosphorylation. They proposed that MMP-9 is up-regulated by TNF- $\alpha$ released in an autocrine fashion. However, we did not observe any increase in ERK phosphorylation by SP 600125 treatment in Raw 264.7 cells. Interestingly, Heidinger et al. (2006) cultured THP-1 cells in absence of serum as we did.

Serum may be a cause of data discrepancy in MMP-9 studies. Similar to JNK, p38 MAPK produced a different response in MMP-9 expression that was dependent on the presence of serum in the culture media. In the presence of $10 \%$ serum, inhibition of p38 MAPK reduces MMP-9 induction in LPS-activated Raw 264.7 cells (Woo et al., 2004), whereas inhibition of p38 MAPK augments MMP-9 expression in LPS-treated rat astrocytes (Shin et al., 2007), or THP-1 monocytic cells (Heidinger et al., 2006) under serum deprivation.

Even though our observations implicate the existence of the inhibitory factor(s) in serum that suppress MMP-9 expression, our experiments were not designed to pinpoint possible inhibitory factor(s). IFN- $\gamma$ suppresses MMP-9 expression through the JAK/STAT pathway (Ma et al., 2005). However, IFN- $\gamma$ could presently be excluded as a candidate, because pyridone 6 did not block the inhibitory effect of mouse serum on MMP-9 expression. TGF- $\beta$, IL-4, or IL-10 may also be a candidate as the inhibitory factor in mouse serum. IL-4 suppresses MMP-9 expression in human monocytes sti- mulated with ConA (Corcoran et al., 1992). TGF- $\beta$ also reduces MMP-9 expression induced by TNF- $\alpha$ in MonoMac-6 monocytic cells (Vaday et al., 2001). In addition, IL-10 inhibits MMP-9 induction by ConA in human monocytes (Mertz et al., 1994). However, the contribution of these factors to the suppression of MMP-9 expression is questionable, since we obtained serum from healthy mice. Similar to serum, the conditioned media also showed the inhibition of MMP-9 induction. However, it is not clear whether both inhibitory factors are identical. At present, we are purifying the inhibitory factor(s) in the conditioned media of Raw 264.7 cells.

In this study, we observed little change in phosphorylation of p65 of NF-kB, which is a well-known transcriptional factor to induce MMP-9 expression. However, we cannot exclude possibility that JNK1 might inhibit NF-kB activity, because we did not determine the transcriptional activity of NF- $\mathrm{kB}$ on the promoter of MMP-9 gene. In drosophila SL2 cells, JNK negatively regulated expression of NF-kB target genes (Kim et al., 2005). JNK caused AP-1 complex to bind to promoters activated by NF-KB, resulting in reduced NF- $\mathrm{kB}$ binding. Interestingly, AP-1 binding led to recruitment of histone deacetylase dHDAC1, and induction of the NF-kB target gene was augmented by inhibition of HDAC activity. From these findings, they proposed that the inhibitory action of JNK/AP-1 is a switch to terminate activation of a group of NF-kB target genes. Therefore, in this context, it needs to be clarified whether the negative regulatory mechanism of JNK/AP-1 is working on MMP-9 expression, and which components of AP-1 complex are responsible for this inhibitory action in the future study.

\section{Methods}

\section{Reagents}

DMEM, BSA, and FBS were purchased from Gibco (Gaithersburg, MD). Control, JNK1, or JNK2 siRNA was purchased from Dharmacon (Chicago, IL). SP600125 was purchased from Alexis (San Diego, CA) and the JAK inhibitor pyridone 6 (P6) was from Calbiochem (San Diego, CA). Antibodies to p-JNK, p-ERK, p-Akt, Akt, p-c-Jun, p-p38 MAPK, and p-p65 were from Cell Signaling Technology (Boston, MA). Antibodies to ERK, $\alpha$-tubulin, and p38 MAPK were purchased from Santa Cruz Biotechnology (Santa Cruz, CA). Antibody to p65 was from Upstate Biotechnology (Lake Placid, NY). LPS (O26:B6), IFN- $\gamma$, gelatin, and other chemicals were acquired from Sigma-Aldrich (St. Louis, MO).

\section{Cell culture}

Raw 264.7 cells from Korean Cell Line Bank (Seoul, 
Korea) were grown in DMEM containing 10\% FBS, 100 $\mathrm{U} / \mathrm{ml}$ penicillin, and $100 \mu \mathrm{g} / \mathrm{ml}$ streptomycin at $37^{\circ} \mathrm{C}$ in a $5 \% \mathrm{CO}_{2}$ humidified incubator. Before experiments, the cells were incubated in DMEM containing $0.02 \%$ BSA overnight, and the media was replaced again $4 \mathrm{~h}$ prior to each experiment. All the data are representative of triplicate experiments.

\section{RT-PCR of MMP-9 mRNA}

RT-PCR was used to determine mRNA expression of MMP-9 and GAPDH. Total RNAs were obtained using a commercial kit (Intron, Sungnam, Korea) according to the manufacturer's instructions. To obtain cDNA, $0.2 \mu \mathrm{g}$ total RNAs were added to a $20 \mu$ reaction mixture containing 15 $\mathrm{U} / \mu \mathrm{l}$ SSII ribonuclease $\mathrm{H}$-reverse transcriptase (Superscript II; Invitrogen), $10 \mathrm{mM}$ Tris- $\mathrm{HCl}$ (pH 8.3), $50 \mathrm{mM} \mathrm{KCl,} 5 \mathrm{mM}$ $\mathrm{MgCl}_{2}, 0.5 \mathrm{mM}$ dNTPs, $2.5 \mu \mathrm{M}$ random hexamers, and 2.5 $\mathrm{U} / \mu \mathrm{l}$ RNase inhibitor. PCR primers for mouse MMP-9 and GAPDH were as follows: MMP-9, 5'-CAAACCCTGCGTATTTCC-3' (sense) and 5'-AGAGTACTGCTTGCCCAGGA3' (antisense); GAPDH, 5'-CTCATGACCACAGTCCATGC3' (sense) and 5'-TTCATCGGGATGACCTT-3' (antisense). PCR was performed with $2 \mu \mathrm{l}$ of cDNA and $0.2 \mathrm{mM}$ primers using a touchdown PCR; 2 cycles of PCR at $94^{\circ} \mathrm{C}$ for 1 min, $64^{\circ} \mathrm{C}$ for $1 \mathrm{~min}$ and $72^{\circ} \mathrm{C}$ for $1 \mathrm{~min}$, followed by 25 cycles (MMP-9) or 20 cycles (GAPDH) of PCR at $94{ }^{\circ} \mathrm{C}$ for $1 \mathrm{~min}, 59^{\circ} \mathrm{C}$ for $1 \mathrm{~min}$ and $72^{\circ} \mathrm{C}$ for $1 \mathrm{~min}$. PCR products (MMP-9, 223 bps; GAPDH, 155 bps) were resolved in $1.5 \%$ agarose gels containing ethidium bromide. Images were taken by a Gel-Doc apparatus (Kodak, Rochester, NY), and analyzed with Image Gauge software (Fuji, Japan).

\section{Assay of MMP-9 activity by gelatin zymography}

The gelatinolytic activity of MMP-9 secreted into the culture medium was determined by gelatin zymography (Chung et al., 2004). Briefly, conditioned media freed of cell debris by centrifugation were mixed with Laemmli buffer lacking reducing agents. After electrophoresis in an $8 \%$ SDSPAGE gel containing $1 \mathrm{mg} / \mathrm{ml}$ gelatin, the gel was incubated in a developing buffer $(20 \mathrm{mM}$ Tris $/ \mathrm{HCl}, \mathrm{pH} 7.8,1 \%$ Triton X-100, $10 \mathrm{mM} \mathrm{CaCl}, 5 \mu \mathrm{M} \mathrm{ZnCl}_{2}$ ) for $24 \mathrm{~h}$ at $37^{\circ} \mathrm{C}$. Thereafter, the gel was stained with $1 \%$ Coomassie Brilliant Blue R-250. Images of gelatinolytic activities were taken and analysis done as described above.

\section{Preparation of conditioned media of Raw 264.7 cells}

Raw 264.7 cells were cultured in DMEM containing 10\% FBS until $80 \%$ confluence. The cells were washed with PBS and incubated in serum- and BSA-free DMEM. Twenty-four hours later, the conditioned medium was collected, and cell debris was removed by centrifugation at $400 \mathrm{~g}$. The conditioned medium was concentrated and fractionated by ultrafiltration using a $10 \mathrm{kDa}$ molecular weight cutoff (Millipore, Billerica, MA).

\section{Western blot analysis}

RAW 264.7 cells were washed with cold PBS and lysed in a cold lysis buffer $(20 \mathrm{mM}$ Tris, $\mathrm{pH} 7.5,150 \mathrm{mM} \mathrm{NaCl}, 1$ mM EDTA, 1 mM EGTA, 1\% Triton X-100, 0.1\% SDS, $1 \%$ NP-40, $2.5 \mathrm{mM}$ sodium pyrophosphate, $1 \mathrm{mM} \beta$-glycerophosphate, $1 \mathrm{mM} \mathrm{Na} \mathrm{VO}_{4}, 2 \mathrm{mM}$ PNPP, and $1 \times$ protease inhibitor cocktail). After centrifugation at $16,000 \mathrm{~g}, 30 \mu \mathrm{g}$ of protein recovered from the supernatant was separated using $12 \%$ SDS-PAGE and the separated proteins were transferred to a PVDF membrane. After blocking with $5 \%$ skim milk in T-TBS $(0.1 \%$ Tween 20 -Tris buffered saline) for $1 \mathrm{~h}$ at room temperature, the membranes were incubated with primary antibodies diluted $1: 1,000$ at $4^{\circ} \mathrm{C}$ overnight, and subsequently with HRP-conjugated secondary antibodies diluted 1:5,000 for $1 \mathrm{~h}$ at room temperature. The proteins were visualized using enhanced chemiluminescence reagents. Images were taken by LAS-3000 (Fuji, Japan), and analyzed with Image Gauge software (Fuji).

\section{Transfection of siRNA}

Transient transfection of siRNA was performed using HiperFect transfection reagent (Qiagen, Valencia, CA) according to the manufacturer's instructions. Raw 264.7 cells $\left(2 \times 10^{5}\right)$ were seeded into wells of a 24 -well plate. siRNA (10-100 nM) was mixed with the transfection reagent, and added to the cells. After $72 \mathrm{~h}, \mathrm{JNK} 1$ and JNK2 protein levels were determined by Western blotting, and total RNAs or culture media were collected for MMP-9 RT-PCR or MMP-9 zymography, respectively.

\section{Acknowledgments}

This work was supported by the Korea Research Foundation Grant funded by the Korean Government (KRF-2007521-E00027).

\section{References}

Arai K, Lee SR, Lo EH. Essential role for ERK mitogenactivated protein kinase in matrix metalloproteinase-9 regulation in rat cortical astrocytes. Glia 2003;43:254-64.

Atkinson JJ, Senior RM. Matrix metalloproteinase-9 in lung remodeling. Am J Respir Cell Mol Biol 2003;28:12-24

Benbow U, Brinckerhoff CE. The AP-1 site and MMP gene regulation: what is all the fuss about? Matrix Biol 1997;15: 519-26

Blom AB, van Lent PL, Libregts S, Holthuysen AE, van der Kraan PM, van Rooijen N, van den Berg WB. Crucial role of macrophages in matrix metalloproteinase-mediated cartilage destruction during experimental osteoarthritis: involvement of matrix metalloproteinase 3. Arthritis Rheum 2007; 56:147-57

Bogoyevitch MA. The isoform-specific functions of the c-Jun $\mathrm{N}$-terminal Kinases (JNKs): differences revealed by gene targeting. Bioessays 2006;28:923-34

Chakrabarti S, Patel KD. Matrix metalloproteinase-2 (MMP-2) and MMP-9 in pulmonary pathology. Exp Lung Res 2005; 31:599-621

Chakraborti S, Mandal M, Das S, Mandal A, Chakraborti T. 
Regulation of matrix metalloproteinases: an overview. Mol Cell Biochem 2003;253:269-85

Cheng JC, Chou CH, Kuo ML, Hsieh CY. Radiation- enhanced hepatocellular carcinoma cell invasion with MMP-9 expression through PI3K/Akt/NF-kappaB signal transduction pathway. Oncogene 2006;25:7009-18

Chung TW, Lee YC, Kim CH. Hepatitis B viral HBx induces matrix metalloproteinase-9 gene expression through activation of ERK and PI-3K/AKT pathways: involvement of invasive potential. FASEB J 2004;18:1123-5

Corcoran ML, Stetler-Stevenson WG, Brown PD, Wahl LM. Interleukin 4 inhibition of prostaglandin E2 synthesis blocks interstitial collagenase and 92-kDa type IV collagenase/ gelatinase production by human monocytes. J Biol Chem 1992;267:515-9

Crowe DL, Tsang KJ, Shemirani B. Jun N-terminal kinase 1 mediates transcriptional induction of matrix metalloproteinase 9 expression. Neoplasia 2001;3:27-32

Deguchi JO, Aikawa M, Tung CH, Aikawa E, Kim DE, Ntziachristos V, Weissleder R, Libby P. Inflammation in atherosclerosis: visualizing matrix metalloproteinase action in macrophages in vivo. Circulation 2006;114:55-62

Eardley KS, Cockwell P. Macrophages and progressive tubulointerstitial disease. Kidney Int 2005;68:437-55

Genersch E, Hayess K, Neuenfeld Y, Haller H. Sustained ERK phosphorylation is necessary but not sufficient for MMP-9 regulation in endothelial cells: involvement of Ras-dependent and -independent pathways. J Cell Sci 2000; 113:4319-30

Gum R, Wang H, Lengyel E, Juarez J, Boyd D. Regulation of $92 \mathrm{kDa}$ type IV collagenase expression by the jun aminoterminal kinase- and the extracellular signal-regulated kinase-dependent signaling cascades. Oncogene 1997;14: 1481-93

Han S, Ritzenthaler JD, Sitaraman SV, Roman J. Fibronectin increases matrix metalloproteinase 9 expression through activation of c-Fos via extracellular-regulated kinase and phosphatidylinositol 3-kinase pathways in human lung carcinoma cells. J Biol Chem 2006;281:29614-24

Heidinger M, Kolb H, Krell HW, Jochum M, Ries C. Modulation of autocrine TNF-alpha-stimulated matrix metalloproteinase 9 (MMP-9) expression by mitogen-activated protein kinases in THP-1 monocytic cells. Biol Chem 2006;387: 69-78

Kim T, Yoon J, Cho H, Lee WB, Kim J, Song YH, Kim SN, Yoon JH, Kim-Ha J, Kim YJ. Downregulation of lipopolysaccharide response in Drosophila by negative crosstalk between the AP1 and NF-kappaB signaling modules. Nat Immunol 2005;6:211-8

Lim EJ, Lee SH, Lee JG, Kim JR, Yun SS, Baek SH, Lee C. Toll-like receptor 9 dependent activation of MAPK and NF-kB is required for the $\mathrm{CpG}$ ODN-induced matrix metalloproteinase-9 expression. Exp Mol Med 2007;39:239-45

Lin CC, Tseng HW, Hsieh HL, Lee CW, Wu CY, Cheng CY, Yang CM. Tumor necrosis factor-alpha induces MMP-9 expression via p42/p44 MAPK, JNK, and nuclear factor-
kappaB in A549 cells. Toxicol Appl Pharmacol 2008;229: 386-98

Ma Z, Chang MJ, Shah RC, Benveniste EN. Interferon- $\gamma-$ activated STAT- $1 \alpha$ suppresses MMP- 9 gene transcription by sequestration of the coactivators CBP/p300. J Leukoc Biol 2005;78:515-23

Matsuguchi T, Musikacharoen T, Johnson TR, Kraft AS, Yoshikai Y. A novel mitogen-activated protein kinase phosphatase is an important negative regulator of lipopolysaccharide-mediated c-Jun N-terminal kinase activation in mouse macrophage cell lines. Mol Cell Biol 2001;21: 6999-7009

Mertz PM, DeWitt DL, Stetler-Stevenson WG, Wahl LM. Interleukin 10 suppression of monocyte prostaglandin $\mathrm{H}$ synthase-2. Mechanism of inhibition of prostaglandindependent matrix metalloproteinase production. J Biol Chem 1994;269:21322-9

Moon SK, Cha BY, Kim CH. ERK1/2 mediates TNF-alphainduced matrix metalloproteinase- 9 expression in human vascular smooth muscle cells via the regulation of NFkappaB and AP-1: Involvement of the ras dependent pathway. J Cell Physiol 2004;198:417-27

Opdenakker G, Van den Steen PE, Dubois B, Nelissen I, Van Coillie E, Masure S, Proost P, Van Damme J. Gelatinase B functions as regulator and effector in leukocyte biology. $J$ Leukoc Biol 2001;69:851-9

Sabapathy K, Hochedlinger K, Nam SY, Bauer A, Karin M, Wagner EF. Distinct roles for JNK1 and JNK2 in regulating JNK activity and c-Jun-dependent cell proliferation. Mol Cell 2004;15:713-25

Sánchez-Tilló E, Comalada M, Xaus J, Farrera C, Valledor AF, Caelles C, Lloberas J, Celada A. JNK1 Is required for the induction of Mkp1 expression in macrophages during proliferation and lipopolysaccharide-dependent activation. J Biol Chem 2007;282:12566-73

Shapiro SD. The maxcrophage in chronic obstructive pulmonary disease. Am J Respir Crit Care Med 1999;160: S29-S32

Shin CY, Lee WJ, Choi JW, Choi MS, Park GH, Yoo BK, Han SY, Ryu JR, Choi EY, Ko KH. Role of p38 MAPK on the down-regulation of matrix metalloproteinase-9 expression in rat astrocytes. Arch Pharm Res 2007;30:624-3

Shin M, Yan C, Boyd D. An inhibitor of c-jun aminoterminal kinase (SP600125) represses c-Jun activation, DNAbinding and PMA-inducible 92-kDa type IV collagenase expression. Biochim Biophys Acta 2002;1589:311-6

Vaday GG, Schor H, Rahat MA, Lahat N, Lider O. Transforming growth factor-beta suppresses tumor necrosis factor alpha-induced matrix metalloproteinase- 9 expression in monocytes. J Leukoc Biol 2001;69:613-21

Van den Steen PE, Proost P, Wuyts A, Van Damme J, Opdenakker G. Neutrophil gelatinase B potentiates interleukin-8 tenfold by aminoterminal processing, whereas it degrades CTAP-III, PF-4, and GRO-alpha and leaves RANTES and MCP-2 intact. Blood 2000;96:2673-81

Waetzig V, Czeloth K, Hidding U, Mielke K, Kanzow M, Brecht 
S, Goetz M, Lucius R, Herdegen T, Hanisch UK. c-Jun $\mathrm{N}$-terminal kinases (JNKs) mediate pro-inflammatory actions of microglia. Glia 2005;50:235-46

Woo CH, Lim JH, Kim JH. Lipopolysaccharide induces matrix metalloproteinase-9 expression via a mitochondrial reactive oxygen species-p38 kinase-activator protein-1 pathway in Raw 264.7 cells. J Immunol 2004a;173:6973-80

Wu CY, Hsieh HL, Jou MJ, Yang CM. Involvement of p42/p44 MAPK, p38 MAPK, JNK and nuclear factor-kappa B in interleukin-1 beta-induced matrix metalloproteinase- 9 expression in rat brain astrocytes. J Neurochem 2004;90:1477-88

Xie B, Dong Z, Fidler IJ. Regulatory mechanisms for the expression of type IV collagenases/gelatinases in murine macrophages. J Immunol 1994;152:3637-44

Xie Z, Singh M, Singh K. Differential regulation of matrix metalloproteinase-2 and -9 expression and activity in adult rat cardiac fibroblasts in response to interleukin-1 $\beta$. J Biol Chem 2004;279:39513-9

Yan C, Boyd DD. Regulation of matrix metalloproteinase gene expression. J Cell Physiol 2007;211:19-26

Zhong S, Fromm J, Johnson DL. TBP is differentially regulated by c-Jun N-terminal kinase 1 (JNK1) and JNK2 through Elk-1, controlling c-Jun expression and cell proliferation. Mol Cell Biol 2007;27:54-64 